\title{
PENAWARAN UANG DALAM KEGIATAN PEREKONOMIAN DAN ORIENTASI BISNIS DALAM ISLAM
}

\author{
Toni Ferdian Apriliano \\ Fakultas Ekonomi dan Bisnis Islam, Institut Agama Islam Negri Ponorogo \\ J1. Pramuka 156 Ponorogo 63471, Jawa Timur. \\ Coresponding email author: ferdiantoni26@gmail.com
}

\begin{abstract}
Abstrak
Penelitian ini bertujuan untuk mengetahui penawaran uang, kegiatan perekonomian, dan orientasi bisnis dalam islam. Dalam transaksi jual beli terdapat suatu permintaan dan penawara, yang mana permintaan dan penawaran akan bertemu pada satu titik. Dan akan selalu ada permintaan dan penawaran disetiap kegiatan perekonomian. Dalam bisnis islam maupun konvensional sangat dibutuhkan uang untuk alat tukar menukar dalam kegiatan perekonomian. Hanya saja dalam bisnis islam setiap tindakan perekonomian diatur sesuai syariat islam. Sehingga orientasi bisnis dalam islam tidaklah hanya mencari keuntungan saja, namun juga memperhatikan keberkahan dan manfaatnya.
\end{abstract}

Kata Kunci : Penawaran uang, kegiatan perekonomian, bisnis dalam islam.

\begin{abstract}
This study aims to determine the money supply, economic activity, and business orientation in Islam. In a sale and purchase transaction there is a demand and a bidder, where the demand and supply will meet at one point. And there will always be demand and supply in every economic activity. In both Islamic and conventional business, money is needed as a medium of exchange in economic activity. It's just that in Islamic business every economic action is regulated according to Islamic law. So that business orientation in Islam is not only looking for profit, but also paying attention to blessings and benefits.

Keywords: Money supply, economic activity, business in Islam.
\end{abstract}

\section{PENDAHULUAN}

Disetiap transaksi dalam perekonomian pasti terdapat suatu permintaan dan penawaran, harga dan kuantitas akan suatu barang atau jasa yang saling mempengaruhi satu sama lainnya. Permintaan dan penawaran akan saling bertemu dan akan membentuk satu titik pertemuan dalam satuan harga dan kuantitas (jumlah barang). Akan selalu ada konssep permintaan dan penawaran disetiap kegiatan perekonomian. Serta dalam kegiatan perekonomian sangat dibutuhkan yang namanya uang sebagai alat tukar menukar dalam perdagangan. Fungsi uang juga beragam seperti untuk alat tukar menukar, sebagai satuan nilai, dan alat untuk menyimpan nilai. Jadi di era sekarang ini perekonomian sangat berkembang pesat dan munculnya berbagai teknologi untuk mempermudah menjalankan kegiatan ekonomi.

Bisnis merupakan bagian dari kegiatan ekonomi dan mempunyai perasaan yang sangat besar dalam rangka memenuhi kebutuhan manusia. Dalam kegiatan bisnis pelaku usaha dan konsumen sama-sama mempunyai kebutuhan dan kepentingan. Pelaku usaha harus mempunyai tanggung jawab terhadap konsumen, karyawan,pemegang saham, dan segala aspek dalam lingkungan perusahaan. Kenyataan yang kita hadapi sekarang adalah perilaku masyarakat yang 
menyimpang ajaran agama, dan merosotnya nilai etika dalam bisnis. Oleh karena itu bisnis perlu adanya orientasi atau tujuan yang tidak hanya focus terhadap profit, namun juga harus ada unsur keberkahan dalam bisnis supaya menghasilkan kemaslahatan.

\section{METODE PENELITIAN}

Penelitian ini menggunakan metode deskriptif yang bertujuan untuk memperoleh deskripsi dari setiap pokokpokok materi yang dibahas. Dengan menggunakan metode deskriptif akan mengetahui pengertian-pengertian dan bagaimana cara berbisnis menurut syariat islam.

\section{PEMBAHASAN Definisi Uang}

Uang didefinisikan sebagai benda benda yang disetujui oleh masyarakat sebagai alat perantaraan mengadakan tukar menukar atau perdagangan. Agar masyarakat menyetujui penggunaan sesuatu benda sebagai uang,benda itu harus memenuhi syarat yaitu :

a) Nilainya tidak mengalami perubahan dari waktu kewaktu

b) Mudah dibawa

c) Mudah disimpan dan tahan lama

d) Jumlahnya terbatas (tidak berlebih lebihan)

e) Bendanya mempunyai mutu yang sama

Kemajuan ekonomi dunia yang bertambah pesat sejak berlakunya revolusi industri dinegara negara maju menyebabkan perdagangan berkembang secara pesat. Sebagai akibatnya bertambah lama bertambah banyak negara menggantikan uang emas dan perak dengan uang kertas sebagai alat tukar menukar.

Perekonomian dapat dibedakan kepada "perekonomian barter" dan "perekonomian uang". Perekonomian barter adalah suatu sistem kegiatan ekonomi masyarakat dimana kegiatan produksi dan perdagangan masih sangat sederhana, kegiatan tukar menukar masih terbatas, dan jual beli dilakukan secara pertukaran barang dengan barang atau jasa. Sedangkan perekonomian uang adalah perekonomian yang sudah menggunakan uang sebagai alat pertukaran dalam kegiatan perdagangan.

\section{Beberapa Kelemahan Perdagangan Barter}

Peranan uang yang sangat penting ini dapat dengan nyata dilihat dari memperhatikan masalah masalah yang akan dihadapi apabila perdagangan dijalankan secara berter. Uraian dibawah ini menerangkan bentuk bentuk masalah yang dihadapi dalam perdaganagan secara bater adalah :

a) Perekonomian barter memerlukan

"Kehendak Ganda yang Selaras"

Yang dimaksud adalah dengan kehendak ganda yang selaras adalah setiap pihak yang ingin melakukan pertukaran memiliki barang yang diingini pihak lain,dan mencari barang yang dimiliki pihak lain. Keadaan seperti itu memungkinkan berlakunya tukar menukar atau barter. Tetapi keadaan seperti itu tidak selalu berlaku.

b) Penentuan harga sukar dilakukan

Dalam kegiatan ini pertukaran dengan menggunakan uang, berbagai barang dapat dengan mudah ditentukan nilainya dengan menyatakannya dalam bentuk jumlah uang yang dibutuhkan untuk memperolehnya. Oleh sebab itu nilai pertukaran sesuatu barang dengan berbagai barang lain harus dibuat,yaitu seperti contoh diatas.

c) Perekonomian barter membatasi pilihan pembeli

Apabila pertukaran dilakukan secara barter, seorang pembeli akan terikat kepada syarat yang ditentukan pihak lain yang mengingini barang yang dimilikinya.

d) Menyulitkan pembayaran tertunda

Dalam perekonomian uang penjualan secara kredit, yaitu 
penjualan dengan pembayaran dimasa yang kemudian, dapat dilakukan dengan mudah. Perjanjian dapat dengan mudah dibuat, yaitu nilai kredit dinyatakan dalam mata uang yang digunakan. Penjualan secara kredit akan dibayar dengan bentuk barang juga dan ini menyukarkan perdagangan karena,timbul masalah untuk menentukan jenis barang yang digunakan untuk pembayaran dan harus dibuat perjanjian mengenai mutu barang yang akan digunakan sebagai pembayaran.

e) Sukar menyimpan kekayaan

Perekonomian modern kekayaan disimpan dalam bentuk uang atau harta harta yang bersifat uang seperti saham,tabungan di bank. Dalam perekonomian barter menyimpan kekayaan sukar dilakukan,karena kekayaan harus disimpan dalam bentuk barang seperti rumah,ternak peliharaan,emas,dan tanah. Dalam perekonomian uang masyarakat mempunyai alternatif yang lebih banyak dalam menyimpan kekayaan dan tidak perlu seluruhnya dalam bentuk barang.

\section{Fungsi Uang}

Peranan atau fungsi uang dalam melancarkan kegiatan perdagangan dibedakan menjadi 4 jenis yaitu :

a) Uang sebagai perantara tukar menukar

Kegiatan tukar menukar akan jauh lebih mudah dijalankan kalau dibandingkan dengan kegiatan perdagangan secara barter. Sesorang yang ingin memperoleh berbagai jenis barang untuk memenuhi kebutuhannya akan dapat dengan mudah memperolehnya apabila ia memiliki uang yang cukup untuk membeli kebutuhan tersebut.

b) Uang sebagai satuan nilai

Yang dimaksud uang sebagai satuan nilai adalah satuan ukuran yang menentukan besarnya nilai dari berbagai jenis barang. Dengan adanya uang, nilai suatu barang dapat dengan mudah dinyatakan, yaitu dengan menunjukkan jumlah uang yang diperlukan untuk memperoleh barang tersebut.

c) Uang sebagai alat bayaran tertunda

Perekonomian yang sudah berkembang banyak sekali dilakukan dengan pembayaran yang ditunda atau penjualan secara kredit. Para pembeli memperoleh barangnya terlebih dahulu dan membayarkannya pada masa yang akan datang. Perkembangan uang sebagai alat tukar menukar dapat mendorong perkembangan perdagangan yang bersifat demikian karena para penjual akan lebih merasa yakin bahwa pembayaran yang ditunda itu adalah sesuai dengan yang diharapkannya. Dengan kata lain, mutu benda yang akan diprolehnya dimasa yang akan datang sebagai pembayaran penjualannya, yaitu uang akan sesuai yang diharapkannya pada waktu menjual barangnnya.

d) Uang sebagai alat penyimpan nilai

Penggunaan uang memungkinkan kekayaan seseorang disimpan dalam bentuk uang. Di dalam perekonomian yang sudah maju, jenis uang yang terutama adalah uang bank atau uang giral. Uang jenis ini tidak memerlukan biaya untuk menyimpannya dan mudah mengurusnnya. Ini disebabkan karena apabila seseorang memiliki uang ini, penyimpanan dan pengurusan uang tersebuat bukan dilakukan oleh pemiliknya, tetapi oleh bank umum yang menyimpan uang tersebut. Jenis kedua dari uang yang sekarang ini banyak digunakan uang kertas. Uang ini juga merupakan alat penyimpan nilai yang lebih baik daripada menyimpan nilai dalam bentuk barang.

\section{Jenis Uang Sepanjang Sejarah}

Uraian berikut ini secara singkat menerangkan perkembangan bentuk uang sepanjang peradaban manusia yaitu :

a) Jenis uang yang mula-mula sekali digunakan

Uang yang mula-mula sekali digunakan terdiri dari barang-barang yang sangat dibutuhkan masyarakat yang banyak 
mereka gunakan dalam kehidupan seharihari, seperti bahan makanan seperti beras , jagung, gandum, ikan, dll.

b) Penggunaan emas dan perak sebagai uang Sifat-sifat yang menyebabkan kedua jenis logam tersebut sangat sesuai untuk digunakan sebagai uang : banyak orang yang menyukai benda tersebut karena dapat digunakan sebagai perhiasan, emas maupun perak mempunyai mutu yang sama, keduaduannya tidak mudah rusak, tetpai dengan mudah dibagi-bagi apabila diperlukan, jumlahnya sangat terbatas dan untuk memperolehnya perlu biaya dan usaha, dan kedua barang itu sangat stabil nilainnya karena mereka tidak berubah mutunya dalam jangka waktu yang panjang dan tidak mengalami kerusakan.

c) Kelemahan penggunaan emas dan perak sebagai uang

Kemajuan ekonomi yang dicapai sesudah refolusi industri menyebabkan perdagangan berkembang dengan pesat. Permintaan keatas emas dan perak untuk digunakan sebagai uang bertambah dengan sangat pesat juga. Maka kesulitan-kesulitan akan timbul yang mana sebab-sebab utamanya adalah Memerlukan tempat yang agak besar untuk menyimpan, Merupakan benda yang berat, Sukar untuk ditambah jumlahnya Penggunaan uang ketas sebagi alat perantara dalam perdagangan menjadi sangat bertambah pesat perkembangannya setelah bank-bank umum mengeluarkan uang kertas tanpa terleih dahulu mereka menerima emas dari para nasabahnya. Dengan demikian setelah periode tersebut uang kertas yang beredar telah melebihi nilai emas yang disimpan oleh bank-bank umum. Oleh sebab itu, walaupun uang kertas yang diciptakan melebihi nilai emas yang disimpan, bank-bank umun akan selalu dapat memenuhi keinginan dari beberapa pemegang uang kertas yang ingin menukarkannya dengan emas. Uang kertas yang sekarang digunakan diberbagai negara bukanlah dikeluarkan oleh bank-bank umum tetapi oleh bank sentral. d) Perkembangan uang giral (Uang Bank)

Walaupun bank-bank umum sudah tidak mempunyai kekuasaan lagi untuk mengeluarkan uang kertas,ini bukan berarti bahwa kekuasaannya untuk menciptakan uang sudah lenyap. Sekarang ini kekuasaan bankbank umum untuk menciptakan uang menjadi sangat bertambah besar. Di negara-negara yang sudah maju sistem keuangannya, bank-bank umum merupakan penciptaan uang yang terutama. Uang yang diciptakan oleh bank-bank umumdinamakan uang giral, selalu disebut juga sebagai uang bank atau rekening koran. Oleh karena bank-bank umum mempunyai peranan yang penting sekali dalan mempengaruhi kegiatan ekonomi..

\section{Penawaran uang dan kegiatan ekonomi Negara.}

Mengenai kebijakan pemerintah, untuk mengendalikan penawaran uang, dengan demikian hakikatnya ada dua hal yaitu; Teori Keuangan yang Utama, Teori kuantitas,teori sisa tunai yang dikemukakan ahli ekonomi Klasik dan teori keuangan Keynes.

\section{Persamaan Pertukaran \\ Teori kuantitas}

Kuantitas uang biasanya diterangkan dengan menggunakan persamaan pertukaran. persamaan pertukaran dinyatakan sebagai berikut :

$\mathrm{MV}=\mathrm{PT}$

Dimana $\mathrm{M}$ adalah penawaran uang, $\mathrm{V}$ adalah laju peredaran uang, $\mathrm{P}$ adalah tingkat harga dan $\mathrm{T}$ adalah jumlah barang barang dan jasa yang diperjualbelikan dalam perekonomian.

Didalam persamaan tersebut $\mathrm{M}$ diartikan sebagai penawaran uang dalam pengertian sempit (M1). Ini berarti M sama dengan mata uan dalam edaran tambah uang bank atau uang giral. Jumlah barang dalam ekonomi yaitu $\mathrm{T}$ mempunyai arti sebagai 
berikut; Ia adalah nilai fisikal dan bukan nilai uang; Ia meliputi barang barang jadi maupun barang setengah jadi.

Oleh karena itu, PT tidak sama nilainya dengan pendapatan nasional. Nilai PT lebih besar dari pendapatan nasional karena meliputi pada transaksi barang barang setengah jadi. Pendapatan nasional adalah nilai barang barang jadi yang di produksikan dalam sesuatu negara pada satun tertentu.

Teori kuantitas uang menurut pandangan adalah perubahan dalam penawaran uang akan menimbulkan perubahan yang sama tingkatnya ke atas harga harga dan perubahan kedua variabel tersebut adalah kearah yang sama.

Apabila menurut asumsi dan pandangan teori kuantitas didasarkan kepada dua asumsi berikut :

\section{Laju peredaran uang,atau $V$ adalah} tetap, menurut para ahli kelajuan peredaran uang tergantung kepada beberapa faktor teknikal seperti sistem pembayaran gaji,ciri ciri kegiatan perdagangan,efisiensi sistem pengangkutan dan kepadatan penduduk. Faktor faktor ini tidak mengalami perubahan dalam jangka pendek, dan oleh karena itu cara cara masyarakat untuk menggunakan uang dan berbelanja tidak berubah.

2. Kesempatan kerja penuh selalu tercapai dalam ekonomi ,oleh karena itu jumlah barang barang adalah tetap dan tidak bisa ditambah.

\section{Teori Sisa Tunai}

Teori ini juga berpendapat bahwa perubahan dalam penawaran uang akan menimbulkan perubahan harga harga yang sama tingkatnya. Teori sisa tunai diterangkan dengan menggunakan persamaan berikut :

$\mathrm{M}=\mathrm{Kpt}$

Dimana M,P,T mempunyai arti yang sama dengan $\mathrm{M}, \mathrm{P}, \mathrm{T}$ dalam persamaan $\mathrm{MV}=\mathrm{PT}$. Kritik kritik ke atas teori kuantitas uang :

a) Pemisalan bahwa $\mathrm{T}$ adalah tetap kurang tepat

b) Laju peredaran uang tidak selalu tetap dalam jangka pendek dan jangka panjang.

c) Perhubungan diantara penawaran uang dan harga adalah lebih rumit dari yang diterangkan oleh teori kuantitas

d) Teori kuantitas hanya memperhatikan funsi uang sebgaia alat untuk melicinkan kegiatan tukar menukar dan transaksi dengan menggunakan uang

e) Teori kuantitas mengabaikan efek perubahan penawaran uang keatas suku bunga.

\section{Pengertian bisnis islam.}

Semua manusia melakukan bisnis. Melalui bisnis manusia mendapatkan penghasilan dan memenuhi kebutuhan sehati-hari. Bisnis bersifat dinamis, mobilitas tinggi. Bergerak dari satu daerah ke daerah lain, ke daerah dimana orang membutuhkan barang. Kegiatan bisnis antara lain menyediakan pada waktu yang tepat dan jumlah, mutu, dan harga yang tepat.

Secara historis bisnis berasal dari bahasa inggris yaitu "bussines" dari asal kata "bussy" yang berarti "sibuk". Sibuk dalam mengerjakan aktifitas dan pekerjaan yang mendatangkan keuntungan. Secara istilah, bisnis dipahami sebagai kegiatan usaha individu yang terorganisasi untuk menghasilkan barang atau jasa guna mendapatkan keuntungan dalam memenuhi kebutuhan masyarakat.

Dari definisi tersebut dapat disimpulkan bahwa bisnis merupakan serangkaian kegiatan yang terdiri dari tukar-menukar, jual-beli, memproduksi-memasarkan, bekerja-memperkerjakan dan interaksi manusia lainnya dengan maksud memperoleh keuntungan. Beberapa etika 
dalam bisnis yang harus dijalankan dalam praktik bisnis islam. Diantaranya adalah halal, thayyibah, jujur dan lain sebagainya. Selain itu, bisnis dalam pandangan islam juga mempunyai visi masa depan yang semata-mata tidak mencari keuntungan sesaat saja, melainkan keuntungan hakiki, berakibat baik pula bagi kemaslahatannya, sehingga dapat meraih keberkahan dan kemaslahatan bersama

\section{Orientasi bisnis dalam islam.}

Dalam menjalankan suatu usaha bisnis, setiap pelaku usaha diwajibkan menentukan dan mengerti betul tentang tujuan bisnis tersebut. Sehingga jika bisnis kita mengalami kerugian atau kebangkrutan, maka kita tetap bangkit dan berjuang kembali sebab tujuan yang kita buat dari awal. Dalam ajaran islam, bisnis memiliki tujuan untuk mencapai 4 hal utama. Diantaranya sebagai berikut:

\section{1) Target Profit}

Dalam bisnis islam, tentunya harus memegang prinsip-prinsip bisnis islami. Menurut Imam Al-Ghozali prinsip-prinsip bisnis islam ialah:

a. Jika seseorang memerlukan sesuatu, maka kita harus memberikan laba yang minimal. Jika perlu, tanpa keuntungan.

b. Jika seseorang membeli barang dari orang miskin, harga sewajarnya dilebihkan.

c. Jika seseorang ada yang berhutang kemudian tak bisa membayar, maka diperpanjang, dan tidak memberatkan.

d. Bagibmereka yang sudah membeli, tidak paus dang ingin mengembalikannya maka harus diterima kembali.

e. Pengutang dianjurkan untuk membayar utangnya lebih cepat. Jika pembayaran dilakukan dengan kredit, maka sebaiknya jangan memaksa pemnayaran jika pembeli belum mampu.

Kesimpulannya, bahwa dalam pengambilan keputusan yang mana dipengaruhi oleh penentuan harga sudah diatur dalam etika bisnis islam. Prinsip saling menguntungkan yaitu agar bisnis dijalankan dengan sedemikian rupa sehingga menghntungkan semua pihak. Prinsip ini mengakomodasi hakikat dan tujuan bisnis.

Hakikat dari bisnis islam, selain mencari keuntungan materi juga mencari keuntungan immaterial. Yang dimaksud immaterial adalah keutungan yang bersifat ukhrawi.

\section{2) Target Hasil}

Tujuan bisnis tidak hanya berfokus mencari profit setinggitingginya, tetapi harus mencari keuntungan benefit nonmateri kepada internal organisasi perusahaan dan eksternal. Seperti terciptanya suasana persaudaraan, kepedulian sosial dan lain sebagainya.

Benefit yang dimaksud bukan hanya memberikan manfaat kebendaan, tetapi juga bersifat immateri. Islam memandang bahwa suatu amal tidak harus berorientasi pada nilai materi. Masih ada orientasi lainnya, yaitu qimah ihsaniyah yang berarti pengelola berusaha memberikan yang bersifat kemanusiaan melalui kesempatan kerja, bantuan sosial dan kegiatan amal yang lainnya. Qiyamul khuluqiyah bahwa yang mengandung nilai-nilai ahlaq mulia suatu kemestian yang harus muncul dalam suatu aktifitas sehingga tercipta hubungan persaudaraan islami, bukan sekedar hubungan profesional. Sedangkan qimah ruhiyah berarti aktifitas dijadikan media untuk mendekatkan diri lepada Allah SWT.

3) Target Pertumbuhan

Jika profit materi dan non materi telah diraih, perusahaan harus berupaya menjaga pertumbuhan agar selalu meningkat. Upaya peningkatan ini juga harus selalu dalam lingkup syariah, bukan menghalalkan segala cara. Serta target yang telah dicapai dengan perumbuhan setiap tahunnya harus dijaga keberlangsungannya agar 
perusahaan dapat exis dalam kurun waktu yang lama.

Bisnis yang Islami merupakan bisnis yang hanya akan hidup secara ideal dalam system dan lingkungan yang Islami pula. Dalam lingkungan yang tidak Islami, maka pelaku bisnis akan mudah sekali terseret dan sulit menghindarkan dari kegiatan yang dilarang oleh agama. Mulai dari uang suap saat perizinan usaha, menyimpan uang dalam rekening bank yang berbunga, hingga iklan yang tidak senonoh, dan kegiatan buruk lainnya. Oleh karena itu, tumbuh tidaknya jenis kegiatan bisnis akan sangat bergantung pada jenis system dan lingkungan yang ada.

4) Target Keberkahan.

Bisnis yang Islami dikendalikan oleh aturan syariah seperti berupa halal dan haram, baik dari cara memperolehnya maupun pemanfaatannya. Sementara bisnis non Islami dilandaskan pada sekurelisme yang bersendikan pada nilainilai material, tidak memperhatikan aturan halal dan haram dalam perencanaan, pelaksanaan dan segala usaha yang dilakukan dalam meraih tujuan bisnis.

Dengan adanya aturan atau ketentuan halal dan haram dalam bisnis Islami, maka lebih menekankan adanya optimalisme daripada maksimalisme. Sebab optimalisme merupakan tindakan yang masih dikendalikan oleh aturan tertentu. Sebagai contoh, hasil penjualan daging yang haram akan menghasilkan jumlah yang banyak. Namaun karena adanya unsur haram,maka daging tersebut tidak diperbolehkan dalam bisnis Islam.

Semua tujuan yang telah dicapai tidak akan berarti apa-apa jika tidak ada unsur keberkahan didalamnya. Maka bisnis Islam menempatkan berkah sebagai tujuan inti dalam bisnis, karena sebagai bukti diterimanya segala aktifitas manusia oleh Allah SWT. Hal ini sesuai dengan tujuan diciptakannya manusia yaitu untuk beribadah kepada Allah baik ibadah mahdah maupun ibadah ghairu mahdah.

\section{PENUTUP \\ Kesimpulan}

Berdasarkan dari penilitian mengenai penawaran uang dalam perekonomian dan orientasi bisnis dalam islam, dapat disimpulkan sebagai berikut :

Definisi uang sebagai alat perantara tukar menukar dalam kegiatan perdagangan ciri-cirinya mudah dibawa kemana-mana, tahan lama, dan nilai tidak mengalami perubahan.

Fungsi uang sebagai perantara tukar menukar, sebagai satuan nilai, sebagai alat pembayaran tertunda, dan sebagai alat penyimpan nilai. Penawaran uang dan harga pandangan klasik meliputi persamaan pertukaran, teori kuantitas uang, dan teori sisa tunai.

Bisnis merupakan serangkaian kegiatan yang terdiri dari tukar menukar, jual beli, memproduksi memasarkan, bekerja memperkerjakan, dan interaksi manusia lainnya dengan maksud memperoleh keuntungan. Islam memberikan aturan atau prinsip tersendiri dalam melakukan bisnis. Diantaranya adalah halal, thayyib, jujur, dan amanah.

Dalam ajaran Islam bisnis bertujuan untuk mencapai empat hal utama yaitu :

1. Target profit materi

2. Target hasil non materi

3. Target pertumbuhan.

4. Target keberkahan

Tujuan bisnis yang semestinya tidak hanya focus untuk mencari profit materi setinggi-tingginya, tetapi juga harus memberikan keuntungan atau manfaat nonmateri kepada internal perusahaan dan eksternal perusahaan, seperti terciptanya persaudaraan dan kepedulian social.

Jika profit materi dan profit non materi telah diraih, perusahaan harus menjaga pertumbuhan agar selalu meningkat. Upaya peningkatan ini juga harus dalam lingkup syariah. Serta pertumbuhan yang telah dicapai harus terus dijaga agar perusahaan dapat exis dalam kurun waktu yang lama. 
Toni Ferdian Apriliano, Penawaran Uang dalam Kegiatan Perekonomian dan Orientasi Bisnis dalam Islam...

\section{REFERENSI}

Alma, Buchari dan Donni Juni Priansa. 2009, Management Bisnis Syariah, Bandung: Alfabeta.

Fauzia, Ika Yunia. 2013, Etika Bisnis dalam Islam, Jakarta: Kencana Media Grup.

Tanjung, M. Azrul, dkk., 2013. Meraih Surga dengan Berbisnis, Jakarta: Gema Insani.

Sukirno Sadono, Makroekonomi Jakarta:Raja Grafindo Persada 2012

Yusanto, Muhammad Ismail dan Muhammad Karebet Widjajakusuma, 2002. Menggagas Bisnis Islami. Jakarta: Gema Insani Press. 